\title{
Ocenění bytu v malé vodní elektrárně
}

\author{
Flat Appraisal in a Small Hydropower Plant \\ Vítězslava Hlavinková*, Martina Vařechová \\ Vysoké učeni technické v Brně, Ústav soudniho inženýrství, Brno
}

\begin{abstract}
Abstrakt
Na podnět majitele malé vodní elektrárny (MVE) bylo zpracováno několik variant řešení vedoucích $\mathrm{k}$ narovnání vlastnických vztahů $\mathrm{k}$ nemovitým věcem. Sousední pozemky nezbytné pro zajištění provozu MVE jsou ve vlastnictví jiného majitele. K zajištění př́istupu bylo potřeba navrhnout rozsah služebnosti. Nestandardní posouzení zahrnovalo i vyřešení problémů spojených $\mathrm{s}$ oceněním bytu $\mathrm{v}$ malé vodní elektrárně, oceněním náhonu a odtoku a dalších inženýrských staveb souvisejících s objektem vodní elektrárny, včetně břehových porostů.
\end{abstract}

Klíčová slova: malá vodní elektrárna, byt, inženýrská stavba, odtok, náhon, břehový porost.

\section{1. ÚVOD}

Znalec se při výkonu své praxe setkává s běžnými problémy, ale někdy je potřeba více se zamyslet nad jednoznačným zatříděním předmětu ocenění. Ne vždy se lze řídit údaji o charakteru objektu uvedenými v katastru nemovitostí. Tak tomu bylo i v následujícím případě ocenění malé vodní elektrárny (dále MVE), v místě mlýna z 1. poloviny 16. století. Mlýn byl postaven na potoku Martálka, jehož průtok byl zesílen stavbou jezu. Původně př́rodní vodní tok se tak stal upraveným korytem, které sloužilo jako náhon a odtok. V současné době toto koryto využívá MVE.

Současný majitel pozemku se stavbou MVE a majitelka sousedních pozemků mají dobrou vůli vyřešit nevyhovující situaci $\mathrm{s}$ př́stupem $\mathrm{k}$ MVE a vlastnictví př́tokového koryta a náhonu, které, přestože tvoří součást MVE, jsou v majetku majitelky okolních pozemků. Dohodli se na provedení směny. Úkolem znalce je navrhnout varianty a vyčíslit hodnotu pro jednotlivá řešení.

\begin{abstract}
At the initiative of the owner of a small hydropower plant (SHP), several options have been developed to lead to the settlement of ownership relations with immovable property. Neighboring land necessary for the operation of the SHP is owned by another owner. To ensure access, it was necessary to propose a range of services. The nonstandard assessment also included solving the problems associated with the appraisal of a flat in a small hydropower plant, the appreciation of the drive and runoff and other engineering structures related to the hydroelectric power plant, including shore stands.
\end{abstract}

Keywords: small hydropower plant, flat, engineering structures, appreciation of drives and outflows, shore stands.

\section{POŽADAVKY ZÚČASTNĚNÝCH STRAN}

Navržené varianty měly splňovat následující požadavky:

- Zajištění přístupu pro nového majitele MVE.

- Zajištění bydlení pro majitelku sousedních pozemků v bytě, ve 2.NP MVE.

- Vyřešení vlastnictví přítokového koryta a náhonu.

Aby bylo možné uskutečnit požadované vyrovnání ke spokojenosti zúčastněných stran, bylo potřeba vymezit a ocenit následující nemovité věci cenou zjištěnou a cenou obvyklou:

- Byt v 2.NP MVE, který zatím není zapsaný v KN jako jednotka.

- Rozsah př́padného věcného břemene pro zajištění príistupu do bytu přes nádvoří MVE.

- Př́tokové koryto vč. všech inženýrských staveb a břehových porostů. 


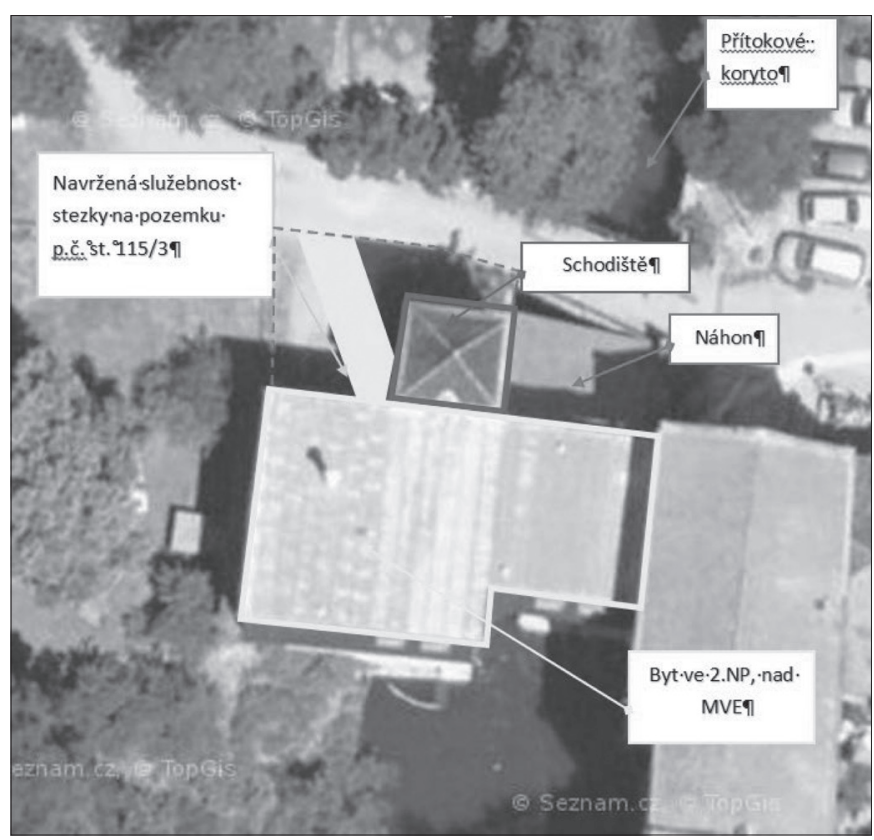

Obr. 1 Situace.

Fig. 1 Situation

Zbývající část MVE v 1.NP a 1.PP sloužící jako strojovna $\mathrm{s}$ turbínami nebyla předmětem posouzení, zůstává v majetku současného vlastníka.

Ocenění bylo provedeno pomocí dvou metod: cenou obvyklou pro účely vyrovnání a současně i cenou zjištěnou pro účely vyměření daně $\mathrm{z}$ nabytí nemovitých věcí. $\mathrm{V}$ tomto případě jsou plátci daně oba účastníci vyrovnání.

\section{OCENĚNÍ BYTU}

\subsection{Určení charakteru objektu, ve kterém se byt nachází}

Již při místním šetření bylo patrné, že před vlastním oceněním bude potřeba správně určit účel užití oceňovaného objektu. Nelze opomenout, co je uvedeno v zákoně č.151/97 Sb., v § 3, odst. 2:

(2) Pro účely oceňováni se stavba posuzuje podle účelu užití. Při nesouladu mezi účelem užití stavby uvedeným v kolaudačním rozhodnutí nebo v kolaudačním souhlasu nebo ve stavebním povoleni nebo ve veřejnoprávni smlouvě nahrazujici stavebni povolení nebo $v$ ohlášeni či v oznámeni stavebnika stavebnímu úřadu nebo v souhlasu stavebního úřadu nebo v certifikátu autorizovaného inspektora a skutečným užitím se vycházi při oceňování ze skutečného užití stavby. Nejsou-li zachovány doklady o účelu, pro který byla stavba povolena, nebo při nesouladu mezi stavem uvedeným v katastru nemovitostí a skutečným stavem platí, že stavba je určena $k$ účelu, pro který je svým stavebně technickým uspořádáním vybavena. Jestliže vybaveni stavby nasvědčuje několika účelům, má se za to, že stavba je určena k účelu, ke kterému se uživá bez závad.

Objekt je jako celek v KN veden jako rodinný dům. Na základě projektové dokumentace z roku 1990 a 1992 doplněné o zjištění skutečného stavu bylo konstatováno, že definici rodinného domu objekt nevyhovuje, protože více než polovina podlahové plochy neodpovídá požadavkům na trvalé rodinné bydlení, a ani není k tomuto účelu určena (\$ 3, odst. 2, 3 vyhl. č. 441/2013 Sb.). Část

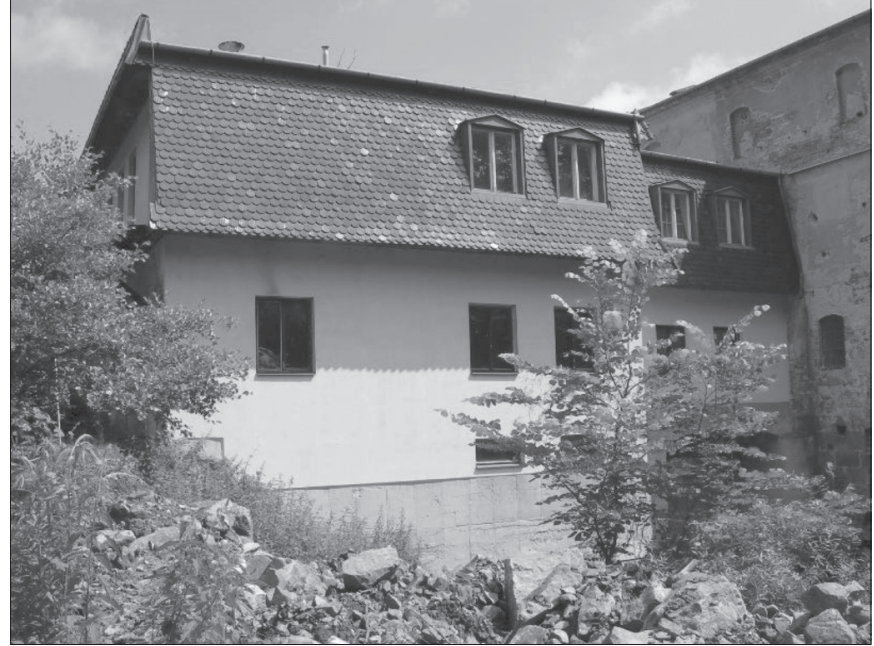

Obr. 2 Pohled jižní.

Fig. 2 South view.

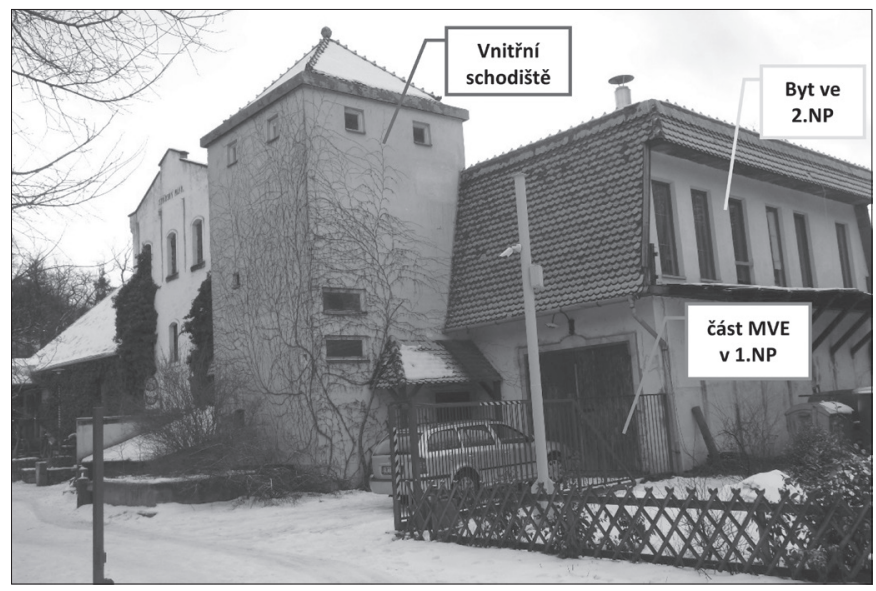

Obr. 3 Pohled severní.

Fig. 3 North view.

objektu byla zkolaudována jako MVE a část ve 2.NP, původně určená pro komerční využití, byla upravena pro trvalé bydlení. Objekt tedy má dva účely užití, proto je třeba se při určení ceny zjištěné ř́́dit ustanovením $\S 28$ pro stavbu s víceúčelovým užitím a doložit výpočtem podlahových ploch převažující účel užití (tab. 1).

Předmětem ocenění není celý objekt, ale jen byt ve 2.NP. Aby bylo možno určit jednotkovou cenu bytu, je třeba nejprve zatřídit objekt, ve kterém se byt nachází, do správného typu budovy. Nadpoloviční část ploch je užívána $k$ výrobě energie, proto objekt požadavky pro rodinný dům nesplňuje a je podle klasifikace stavebních děl CZ-CC zatříděn ke kódu 125112 Budovy pro energetiku.

Podle vyhlášky č. 441/2013 Sb., v aktuálním znění, se jedná o typ budovy $\mathrm{M}$, do jejichž účelu užití patří budovy výrobní pro energetiku (stavby elektráren, díla energetická výrobní). Ocenění bylo provedeno dle $\S 28$ a následně podle $\S 10$, $\S 11$ a $\S 21$ nákladovým způsobem, podle oceňovacího předpisu, v aktuálním znění.

\section{2 Řešení oddělení bytu}

Pro oddělení bytu byly podrobněji rozpracovány varianty vyhovující oběma stranám. Především bylo potřeba vyjasnit budoucí vlastnické 
Tab. 1 Výpočet podlahových ploch.

Tab. 1 Calculation of floor areas.

\begin{tabular}{lrrr}
\hline Budova č. p. 1489 - část MVE v 1.NP a 1.PP & Délka [m] & Šíŕka [m] & PP [m²] \\
\hline Místnost turbíny č. 1 & 7,80 & 7,80 & 60,84 \\
Místnost turbíny č. 2 & 10,40 & 10,40 & 108,16 \\
Náhon & 4,10 & 2,20 & 9,02 \\
Šachta & 4,10 & 2,00 & 8,20 \\
Místnost turbíny č. 1 & 7,80 & 7,80 & 60,84 \\
Místnost turbíny č. 2 & 10,40 & 10,40 & 108,16 \\
Náhon & 8,30 & 5,46 & 45,32 \\
& 7,30 & 0,18 & $-1,28$ \\
\hline Místnosti MVE celkem & & & $\mathbf{3 9 9 , 2 6}$ \\
\hline
\end{tabular}

\begin{tabular}{|c|c|c|c|c|}
\hline Jednotka v budově č. p. 1489: & Délka [m] & Šířka [m] & $\mathbf{P P}\left[\mathbf{m}^{2}\right]$ & Plocha pro ocenění \\
\hline Zádveří & 2,37 & 1,15 & 2,73 & 2,73 \\
\hline \multirow{8}{*}{ Kuchyň 2.06} & 3,00 & 3,21 & 9,63 & 9,63 \\
\hline & 3,07 & 2,25 & 6,91 & 6,91 \\
\hline & 1,48 & 4,44 & 6,57 & 6,57 \\
\hline & 1,00 & 0,70 & 0,70 & 0,70 \\
\hline & 0,64 & 1,00 & 0,64 & 0,64 \\
\hline & 5,01 & 5,37 & 26,88 & 26,88 \\
\hline & 4,37 & 4,35 & 18,99 & 18,99 \\
\hline & 0,90 & 3,45 & 3,10 & 3,10 \\
\hline Pokoj 2.01 & 4,30 & 5,57 & 23,95 & 23,95 \\
\hline Pokoj 2.02 & 1,84 & 2,81 & 5,17 & 5,17 \\
\hline \multirow{4}{*}{ Pokoj 2.03} & 4,05 & 5,35 & 21,67 & 21,67 \\
\hline & 1,63 & 0,15 & 0,24 & 0,24 \\
\hline & 0,94 & 3,21 & $-3,02$ & $-3,02$ \\
\hline & 0,41 & 2,75 & $-1,11$ & $-1,11$ \\
\hline Pokoj 2.05 & 4,30 & 3,53 & 15,18 & 15,18 \\
\hline \multirow{2}{*}{ Pokoj 2.10} & 2,73 & 0,73 & 1,99 & 1,99 \\
\hline & 1,95 & 1,77 & 3,45 & 3,45 \\
\hline Galerie 2.11 & 3,00 & 2,15 & 6,45 & 6,45 \\
\hline Galerie 3.01 - zešikmený strop pod 2,00 m, odpočet & 4,26 & 4,55 & 19,37 & $-15,50$ \\
\hline Koupelna 2.04 & 4,50 & 1,75 & 7,84 & 7,84 \\
\hline Koupelna 2.08 & 2,50 & 3,85 & 9,63 & 9,63 \\
\hline \multirow{2}{*}{ WC 2.09} & 1,75 & 1,67 & 2,91 & 2,91 \\
\hline & 1,55 & 0,83 & 1,28 & 1,28 \\
\hline \multirow{4}{*}{ Chodba 2.07} & 7,68 & 1,73 & 13,29 & 13,29 \\
\hline & 2,05 & 1,90 & 3,90 & 3,90 \\
\hline & 2,37 & 1,38 & 3,26 & 3,26 \\
\hline & 0,13 & 1,00 & 0,13 & 0,13 \\
\hline Schodiště & 2,10 & 4,30 & 9,03 & 9,03 \\
\hline Místnosti bytové jednotky celkem & 2,10 & 4,30 & 218,03 & 216,89 \\
\hline
\end{tabular}

vztahy pro schodiště mezi 1.NP a 2.NP. Dvouramenným schodištěm je přístupný pouze byt, oddělením schodiště nebude provoz MVE narušen, protože část objektu s turbínami má samostatný vstup dvoukřídlovými vraty.
- Varianta 1: pozemek se spoluvlastnickým podílem vč. schodiště ve spoluvlastnickém podílu a atypický byt $5+1$ v 2.NP, budovy č.p. 1489, včetně spoluvlastnického podílu na společných prostorách (schodiště), spoluvlastnického 


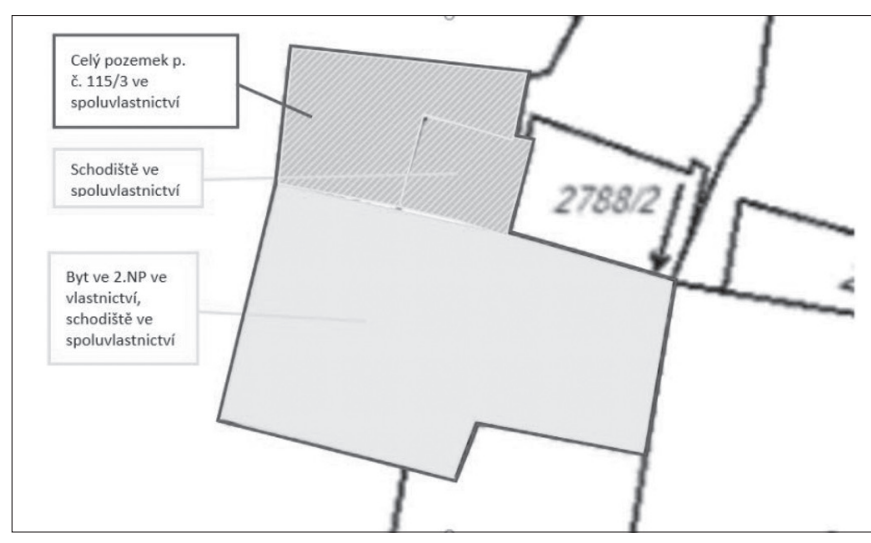

Obr. 4 Schéma pro var. 1.

Fig. 4 Scheme for the var. 1 .

podílu na pozemku p.č. st. 115/3 a okrasných porostech, katastrální území Kounické Předměstí (obr. 4, tab. 2, 3).

- Varianta 2: pozemek se spoluvlastnickým podílem bez schodiště a atypický byt $5+1$ v 2.NP, budovy č.p. 1489 , včetně společných prostor (schodiště) a spoluvlastnického podílu na pozemku p.č. st. 115/3 a okrasných porostech, katastrální území Kounické Předměstí (obr. 5, tab. 4, 5).

- Varianta 3: atypický byt 5+1 v 2.NP, budovy č.p. 1489, včetně společných prostor (schodiště) a zřízení věcného břemene (služebnosti stezky viz kapitola 4.2) na části pozemku p.č. st. $115 / 3$ nádvoří před vstupem, které by zajišt'ovalo přístup $\mathrm{k}$ nemovitosti, katastrální území Kounické Předměstí. Spoluvlastnický podíl pro byt bude stejný jako ve variantě 2 . Předmětem prodeje nebude pozemek, ani podíl na pozemku, protože bude zř́zeno věcné břemeno (obr. 6, tab. 6).

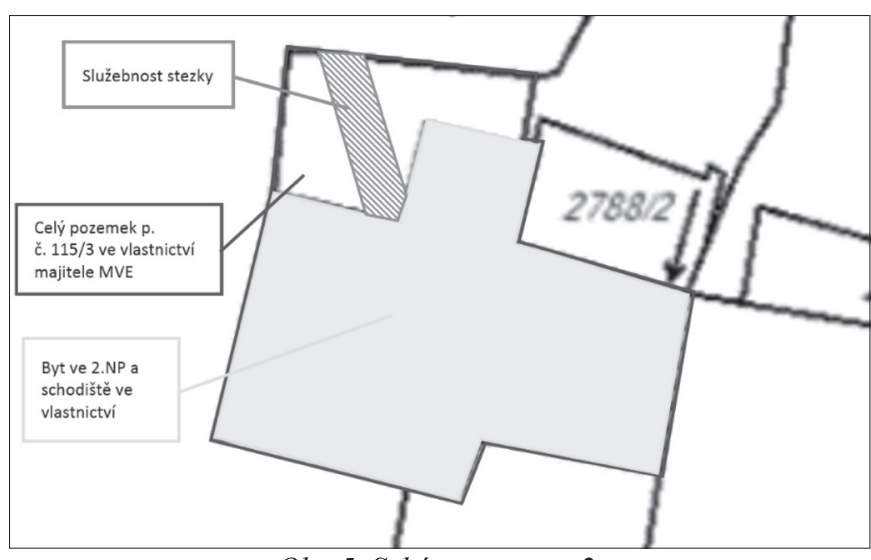

Obr. 5 Schéma pro var. 2.

Fig. 5 Scheme for the var. 2.

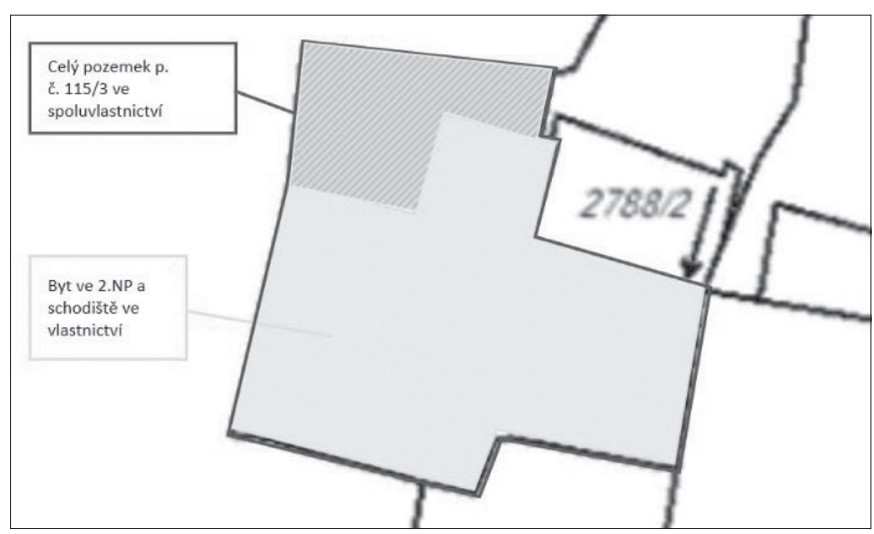

Obr. 6 Schéma pro var. 3.

Fig. 6 Scheme for the var. 3.

Tab. 2 Výpočet spoluvlastnického podílu pro variantu 1.

Tab. 2 Calculation of co-ownership for Option 1.

\begin{tabular}{lc}
\hline Celková podlahová plocha bytu bez společných prostor bez schodiště & $207,86 \mathrm{~m}^{2}$ \\
Celková podlahová plocha v budově bez společných prostor bez schodiště & $607,12 \mathrm{~m}^{2}$ \\
Výpočet výše spoluvlastnického podílu pro bytovou jednotku bez schodiště & $20786 / 60712$ \\
\hline
\end{tabular}

Tab. 3 Výpočet ceny pro variantu 1.

Tab. 3 Price calculation for option 1.

\begin{tabular}{lccc}
\hline $\begin{array}{l}\text { Výchozí metody pro stanovení } \\
\text { obvyklé ceny }\end{array}$ & $\begin{array}{l}\text { Cena stavby, včetně ceny } \\
\text { společných prostor a porostů } \\
\text { ve výši spoluvlastnického podílu }\end{array}$ & $\begin{array}{l}\text { Cena pozemku ve výši } \\
\text { spoluvlastnického podílu }\end{array}$ & $\begin{array}{l}\text { Cena stavby, včetně } \\
\text { pozemku }\end{array}$ \\
\hline $\begin{array}{l}\text { Cena zjištěná dle cenového předpisu } \\
\text { (pro daň z převodu nemovitostí) }\end{array}$ & $1838853,45 \mathrm{Kč}$ & $46388,36 \mathrm{Kč}$ & $1885241,80 \mathrm{Kč}$ \\
\hline Odhad ceny obvyklé & & $\mathbf{2 1 0 0 0 0 0 , 0 0 ~ K c ̌ ~}$ \\
\hline
\end{tabular}

Tab. 4 Výpočet spoluvlastnického podilu pro variantu 2.

Tab. 4 Calculation of co-ownership for Option 2.

\begin{tabular}{lc}
\hline Celková podlahová plocha bytu bez společných prostor se schodištěm & $216,89 \mathrm{~m}^{2}$ \\
Celková podlahová plocha v budově bez společných prostor se schodištěm & $616,15 \mathrm{~m}^{2}$ \\
Výpočet výše spoluvlastnického podílu pro bytovou jednotku se schodištěm & $21689 / 61615$ \\
\hline
\end{tabular}


Tab. 5 Výpočet ceny pro variantu 2.

Tab. 5 Price calculation for option 2.

\begin{tabular}{lccc}
\hline $\begin{array}{l}\text { Výchozí metody pro stanovení } \\
\text { obvyklé ceny }\end{array}$ & $\begin{array}{l}\text { Cena stavby, včetně ceny } \\
\text { společných prostor a porostů } \\
\text { ve výši spoluvlastnického podílu }\end{array}$ & $\begin{array}{l}\text { Cena pozemku ve výši } \\
\text { spoluvlastnického podílu }\end{array}$ & $\begin{array}{l}\text { Cena stavby, včetně } \\
\text { pozemku }\end{array}$ \\
\hline $\begin{array}{l}\text { Cena zjištěná dle cenového předpisu } \\
\text { (pro daň z převodu nemovitostí) }\end{array}$ & $1890618,12 \mathrm{Kč}$ & $47694,21 \mathrm{Kč}$ & $1938312,33 \mathrm{Kč}$ \\
\hline Odhad ceny obvyklé & & $\mathbf{2 3 0 0 0 0 0 , 0 0 ~ K c ̌ ~}$ \\
\hline
\end{tabular}

Tab. 6 Výpočet ceny pro variantu 3.

Tab. 6 Price calculation for option 3

\begin{tabular}{lccc}
\hline $\begin{array}{l}\text { Výchozí metody pro stanovení } \\
\text { obvyklé ceny }\end{array}$ & $\begin{array}{l}\text { Cena stavby, včetně } \\
\text { společných prostor }\end{array}$ & Cena věcného břemene & $\begin{array}{l}\text { Cena stavby, včetně } \\
\text { služebnosti na pozemku }\end{array}$ \\
\hline $\begin{array}{l}\text { Cena zjištěná dle cenového předpisu } \\
\text { (pro daň z převodu nemovitostí) }\end{array}$ & $1890342,88 \mathrm{Kč}$ & $7500,00 \mathrm{Kč}$ & $1897842,88 \mathrm{Kč}$ \\
\hline Odhad ceny obvyklé & $2220200,00 \mathrm{Kč}$ & $13104,56 \mathrm{Kč}$ & $\mathbf{2 2 3 3 3 0 0 , 0 0 ~ K c ̌ ~}$ \\
\hline
\end{tabular}

\section{VĚCNÉ B ŘEMENO}

\subsection{Rozsah věcného břemene pro variantu 3}

Dostatečná plocha pro zajištění př́stupu ke vchodu do budovy č.p. 1489 byla navržena $5,75 \mathrm{~m} \times 1,20 \mathrm{~m}=6,90 \mathrm{~m}^{2}$. Věcné břemeno služebnosti stezky by zatěžovalo pozemek povinného (majitele MVE) ve prospěch oprávněného (majitelky bytu).

\subsection{Ocenění věcného břemene}

Pro určení ceny zjištěné věcného břemene je určující především výše ročního užitku. I když je věcné břemeno zřízeno na dobu neurčitou, je podle $\S 16 \mathrm{~b}$, odst. 3 násobeno nejvýše 5 lety uživání práva. Výše dosažitelného ročního nájemného obdobných pozemků v dané lokalitě není dohledatelná, proto nájemné za $6,90 \mathrm{~m}^{2}$ bylo určeno odhadem na $217,00 \mathrm{Kč} / \mathrm{m}^{2}$ (1 500,00 Kč/rok) a služebnost se ocení podle $\S 16 \mathrm{~b}$ ) odstavec 1 zákona.

Právo odpovídající věcnému břemeni by činilo:

$$
217,00 \mathrm{~K} \check{c} / \mathrm{m}^{2} \times 6,90 \mathrm{~m}^{2} \times 5 \mathrm{let}=7500 \mathrm{Kc \check {c }}
$$

Pro určení ceny obvyklé věcného břemene je výpočet proveden v tab. 7.

\section{PŘíTOKOVÉ KORYTO A NÁHON}

5.1 Určení charakteru objektů přítokového koryta a náhonu Pozemky, na kterých je umístěno přítokové koryto a náhon, nejsou v držení vlastníka MVE. Při jejich ocenění bylo nutné zvážit, jakým způsobem posoudit stavby, které se na pozemcích nacházejí. Využito bylo ustanovení $§ 55$ Vodního zákona č. 254/2001 Sb.:

(1) Vodni dila jsou stavby, které slouži ke vzdouvání a zadržování vod, umělému usměrňováni odtokového režimu povrchových vod, $k$ ochraně a uživání vod, $k$ nakládáni s vodami, ochraně pred škodlivými účinky vod, $k$ úpravě vodních pomérů nebo $k$ jiným účeliom sledovaným tímto zákonem, a to zejména:

b) stavby, jimiž se upravuji, méní nebo zřizuji koryta vodnich tokù, g) stavby k využití vodní energie a energetického potenciálu.
Přítokové koryto a náhon jsou vodním dílem podle odstavce b), funkčně souvisí se stavbou MVE, vodním dílem podle odstavce g). Toto je rozhodující pro ocenění pozemku pod přítokovým korytem a náhonem jako pozemek vodní plochy.

\subsection{Popis přítokového koryta vč. inženýrských staveb a břehového porostu}

Pozemek je v katastru nemovitostí (ve veřejném seznamu) evidován jako vodní plocha se způsobem využití koryto vodního toku přirozené nebo upravené a má výměru $1240 \mathrm{~m}^{2}$. Jeho součástí jsou inženýrské stavby (opěrná zed', lávka, most a úprava toku) a břehový listnatý porost s doprovodnou zelení vodního toku, která je převážně zařazena ve skupinách dřevin buku a olše.

Pozemek sousedí s objektem MVE, který byl postaven a zkolaudován v roce 2000 v těsné blízkosti Stř́ibského mlýna.

\subsection{Popis náhonu}

Pozemek je v katastru nemovitostí (ve veřejném seznamu) evidován jako vodní plocha se způsobem využití koryto vodního toku

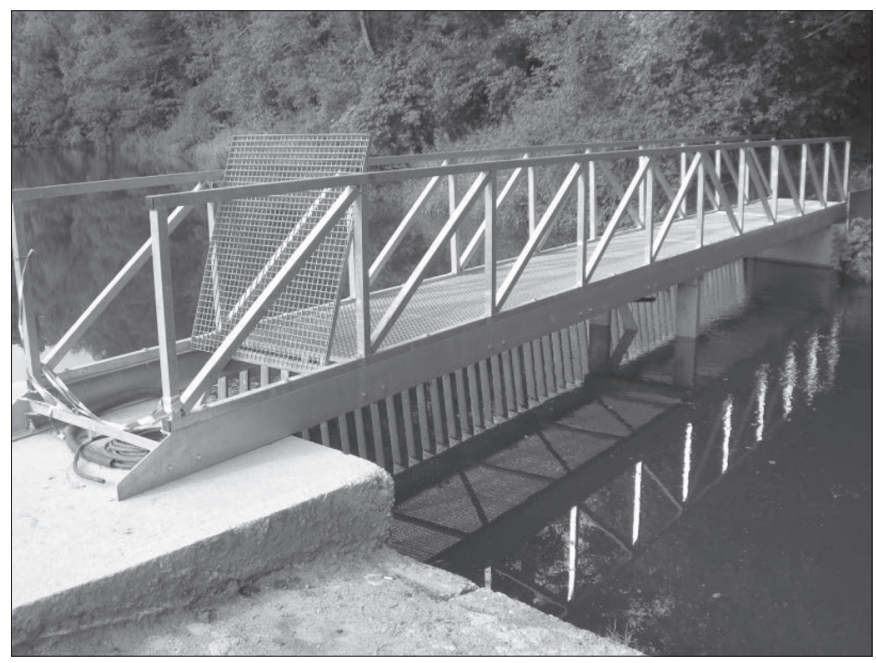

Obr. 7 Kovová lávka s česly.

Fig. 7 Metal bridge with rails. 
Tab. 7 Výpočet ceny služebnosti pro variantu 3.

Tab. 7 Calculation of Service Price for Option 3.

\section{Údaje o služebnosti}

Druh a obsah služebnosti

Přepokládaná plocha pozemku p. č. St. $115 / 3$ před vstupem do budovy č. p. 1489 , jejíž součástí je byt $5+1$ v 2 . NP, na které by bylo zřízeno věcné břemeno (služebnost stezky), je 5,75 $\mathrm{m} \times 1,2 \mathrm{~m}=6,90 \mathrm{~m}^{2}$.

Přesné určení nemovité věci, na níž služebnost vázne

Pozemek p. č. St. 115/3, k. ú. Kounické Předměstí, město Ivančice, okres Brno-venkov

Oprávněný: Majitel bytu 5+1 v budově MVE

Povinný: Majitel pozemku s budovou MVE

Výpočet ročního užitku oprávněné osoby

a) užitek bez odpočtu nákladů na opravy a zachování věci

Nájemné jednotkové dosažitelné ročně

$\mathrm{K} \check{c} / \mathrm{m}^{2}$

$\mathrm{m}^{2}$

Výměra

Kॅ̆

Užitek ročně celkem

b) náklady na opravy a zachování věci (§ 1263 nového obč. zákoníku - poměrný díl připadající na oprávněného)

Je ve smlouvě o zřízení věcného břemena stanovena povinnost oprávněného přiměřeně nést na opravy

a zachování věci?

Pokud není ve smlouvě stanoveno, výpočet nákladů oprávněného na opravy a zachování věci

Daň z nemovitostí - celá nemovitost ročně Ǩ

Pojištění nemovitostí - celá nemovitost ročně

Náklady na opravy a běžnou údržbu, která by nepř́slušela nájemci nemovitostí - celá nemovitost ročně

Amortizace staveb kapitalizovaná ročně

Kс̌

Správa nemovitostí ročně - celá nemovitost

Nájemné z pozemku, na němž stojí stavba, na níž vázne věcné břemeno - ročně

Náklady na opravy a zachování věci celkem - celá nemovitost

Výpočet podílu, jímž by se oprávněný z věcného břemene měl podílet na nákladech na opravy a zachování věci

Výměra služebnosti (stezky) na pozemku p.č. st. 115/3

Výměra pozemku p.č. st. 115/3

$\mathrm{m}^{2}$

Z toho podíl oprávněného na užívání nemovitosti

Náklady na opravy a zachování věci celkem - podíl připadající na oprávněného z věcného břemene - zjištěno výpočtem

$\%$

Náklady na opravy a zachování věci celkem - podíl připadající na oprávněného z věcného břemene - hodnota použitá pro ocenění

$\mathrm{K} \check{c}$

Užitek oprávněného roční celkem po odpočtu nákladů na opravy věci

$\mathrm{K} \check{c}$

\section{Výpočet ceny služebnosti výnosovým způsobem}

Lze zjistit roční užitek ze smlouvy, z výsledků řizení o dědictví nebo z rozhodnutí příslušného orgánu?

Uvažovaná přiměřená výše ročního užitku dle názoru odhadce (U)

$\mathrm{Kč}$

1050,00

Jedná se o věcné břemeno na dobu života oprávněného?

Zbývající počet let uživání práva (n)

roků

Vztah pro výpočet ceny služebnosti

Míra kapitalizace (úroková míra) ročně pro výpočet výnosové hodnoty

Míra kapitalizace setinná (i)

Tab. 8 Rekapitulace cen pozemkü.

Tab. 8 Recapitulation of land prices.

\begin{tabular}{lcc}
\hline Pozemky & Cena zjištěná & Cena obvyklá \\
\hline Pozemek pod př́tokovým korytem vč. inženýrských staveb a břehových porostů & 706 406,27 Kč & 74400,00 Kč \\
Pozemek pod náhonem & 2654,96 Kč & 1760,00 Kč \\
Celkem & 709061,23 Kč & 76160,00 Kč \\
\hline
\end{tabular}


přirozené nebo upravené a má výměru $44 \mathrm{~m}^{2}$. Na celou výměru pozemku zasahuje část budovy MVE. V této části stavby vede náhon ke strojovně malé vodní elektrárny s hrabačkou a jemnými česly.

\section{POSOUZENÍ VÝHODNOSTI VARIANT SMĚNY}

Při srovnání tř́ navržených variant je zjevné, že rozdíl mezi jednotlivými variantami je cca 200000 Kč, což je částka, která významně přesahuje cenu pozemků funkčně spojených s MVE.

Ze srovnání ceny bytu a ceny pozemků plyne, že cena pozemků v dané lokalitě je nízká, je však třeba uvést, že byly použity cenové údaje poskytnuté Povodím Moravy a.s., takže cena je korektně doložena. Z definice obvyklé ceny vyplývá, že $\mathrm{v}$ ní nemá být zahrnut, a v tomto případě ani zahrnut nebyl, vliv zvláštní obliby.

Obě strany na směnu zdánlivě nevýhodnou přistoupily, roli zde sehrál právě „,vliv zvláštní obliby“: jedna ze stran získala byt na atraktivním místě, druhá strana vyřešila vlastnictví pozemků nezbytných pro chod MVE.

Tab. 9 Shrnutí variant směny.

Tab. 9 Summary options Exchange.

\begin{tabular}{lc}
\hline Pozemky + byt Varianta 1 & Cena obvyklá \\
\hline Byt - Varianta 1 & 2100000,00 Kč \\
Pozemky funkčně související s MVE & 76160,00 Kč \\
\hline & \\
\hline Pozemky + byt Varianta 2 & Cena obvyklá \\
\hline Byt - Varianta 2 & 2300000,00 Kč \\
Pozemky funkčně související s MVE & 76160,00 Kč \\
\hline & \\
\hline Pozemky + byt Varianta 3 & Cena obvyklá \\
\hline Byt - Varianta 3 & 2233300,00 Kč \\
Pozemky funkčně související s MVE & 76160,00 Kč \\
\hline
\end{tabular}

\section{ZÁVĚR}

Požadavkům obou stran bylo vyhověno, podařilo se navrhnout narovnání vlastnických vztahů a každá ze stran má svůj pozemek, př́padně odpovídající podíl na pozemku.

V zájmu každého vlastníka nemovitosti by mělo být vlastnit pozemek pod vlastní stavbou a mít zajištěný př́istup $\mathrm{k}$ vlastním pozemkům. Nehrozí tak nebezpeční placení vysokého nájemného z pozemku, odpadá i nutnost zř́zení práva stavby. $V$ tomto prípadě udělali vlastníci nutné kroky k narovnání vlastnických vztahů (dle zákona č. 256/2013 Sb., o katastru nemovitostí), aby se stavba stala součástí pozemku. Zákon sice řeší narovnání vlastnických vztahů $\mathrm{k}$ nemovitostem, neřeší ale motivaci majitelů staveb. Zákonodárci by se mohli inspirovat vydanými nařízeními císaře Karla IV., který od daně a povinných dávek osvobodil poddané, kteří respektovali jeho záměry, např́ílad výstavbou kamenných domů více odolných požáru. V současné době by bylo přiměřené, aby převody směřující k narovnání vlastnických vztahů k pozemkům byly osvobozeny od daně z nabytí nemovité věci.

\section{LITERATURA}

[1] BRADÁČ, A. a kol.. Teorie a praxe oceňování nemovitých věcí. CERM Brno, 2016, 790 s. ISBN 978-80-7204-930-1.

[2] Zákon č. 151/1997 Sb., o oceňování majetku ve znění zákona č. 121/2000 Sb., zákona č. 237/2004 Sb., zákona č. 257/2004 Sb., zákona č. 296/2007 Sb., zákona č. 188/2011 Sb., zákona č. 350/2012 Sb., č. 303/2013 Sb., č. 340/2013., č. 344/2013., č. 228/2014 Sb., a č. 225/2017 Sb.

[3] Vyhláška MF ČR č. 441/2013 Sb., k provedení zákona o oceňování majetku zákona č. 151/1997 Sb., ve znění vyhlášky č. 199/2014 Sb., vyhlášky č. 345/2015 Sb., 53/2016 sb. a vyhlášky č. 457/2017 Sb. (dále jen ,cenový předpis“).

[4] Malý lexikon obcí ČR 2017. Český statistický úřad, 15. 12. 2017.

[5] Zákon č. 289/1995 Sb., o lesích a o změně a doplnění některých zákonů.

[6] Vyhláška č. 84/1996 Sb., o lesním hospodářském plánování.

[7] Zákon č. 254/2001 Sb., o vodách a o změně některých zákonů, v aktuálním znění.

[8] ČSN 752601 - Malé vodní elektrárny - Základní požadavky.

[9] Zákon č. 256/2013 Sb., o katastru nemovitostí, v aktuálním znění.

\section{Správná citace:}

Hlavinková, V., Vařechová, M. Ocenění bytu v malé vodní elektrárně. Soudní inženýrství, 2018, 29(4), 37-43. DOI: http://dx.doi. org./10.13164/SI.2018.4.37. ISSN 1211-443X. 